\title{
Spinal muscular atrophy-Dandy-Walker malformation-cataracts syndrome
}

INSERM

\section{Source}

INSERM. (1999). Orphanet: an online rare disease and orphan drug data base. Spinal muscular atrophy-Dandy-Walker malformation-cataracts syndrome. ORPHA:73245

Spinal muscular atrophy-Dandy-Walker malformation-cataracts syndrome is characterised by infantile symmetrical distal muscle weakness and atrophy of the lower limbs, bilateral anterior polar cataracts and Dandy-Walker malformation. It has been described in two brothers. No sensorineural or cog nitive deficits were observed. The karyotypes of the two patients were normal. No mutations were found in the survival motor neurone (SMN), neuronal apoptosis inhibitory protein (NAIP) or androgen receptor genes. 